\title{
Asymmetric Michael addition using sugar derived organocatalysts
}

\author{
P.B. Lalthanpuii ${ }^{1,2}$, C. Lalhriatpuia ${ }^{1}$, K. Vanlaldinpuia ${ }^{1 *}$ \\ ${ }^{\mathrm{I}}$ Department of Chemistry, ${ }^{2}$ Department of Zoology, Pachhunga University College, Aizawl 796oor, Mizoram
}

\begin{abstract}
Sugars are low-molecular-weight carbohydrates which consist of polyhydroxyl and carbony (aldehyde or ketone) functional groups. Different types of compounds derived from sugars have been used extensively as powerful and effective catalysts for asymmetric synthesis. They are readily available at a reasonable price, easily prepared, no metal contamination and are inert towards moisture and air. They are highly functionalized and have well defined stereogenic centres. Most of them are employed as chiral ligands in metal based asymmetric catalysis and are used for various asymmetric transformations. Different compounds derived from sugars have also been used recently as organocatalysts for asymmetric synthesis. The present article provides some of the organocatalysts used for asymmetric synthesis.
\end{abstract}

Key words: Asymmetric Michael addition, organocatalysts, sugar.

\section{Received 06 June 2017 \\ Accepted o7 August 2017 \\ *For correspondence $\mathbb{M}$} mapuiakhiangte@gmail.com

\section{Introduction}

The word 'sugar' is often signified as a synonym for carbohydrates in general, but in everyday usage it means the table sugar, sucrose. ${ }^{1}$ The carbohydrates (saccharides) are a group of organic compounds which consists of polyhydroxyl and carbonyl (aldehyde or ketone) functional groups with the capability of forming an intramolecular hemiacetal or hemiketal. ${ }^{2,3}$ They are divided into three groups namely: monosaccharides, oligosaccharides, and polysaccharides. The nomenclature suffix "-ose" is used to denote carbohydrates. The name carbohydrate originates from "carbon hydrate" (hydrate of carbon), as they were originally believed to consist solely of carbon and water and thus were commonly designated by the generalised formula $\mathrm{C}_{\mathrm{x}}\left(\mathrm{H}_{2} \mathrm{O}\right)_{\mathrm{y}}{ }^{4}$
Nowadays, the definition of carbohydrates has been much expanded to include substances derived from reduction or oxidation of monosaccharides and also those containing other elements (nitrogen, sulphur and halogens). ${ }^{5}$

Generally, among the carbohydrates mentioned above, monosaccharides and oligosaccharides (usually disaccharides and trisaccharides) having lower molecular weight are commonly referred to as sugars. ${ }^{6}$

Monosaccharides (Fig. 1) are divided into two main groups depending on which carbonyl functionalities they contain: "aldoses" for those containing aldehyde and "ketoses" for those having ketone functional group. ${ }^{4}$ They can further be classified according to the number of carbon atoms in the monomeric chain into triose $(\mathrm{n}=3)$, tetrose $(n=4)$, pentose $(n=5)$, hexose $(n=6)$, 
<smiles>OCC1OC2OC(O)C(C1O)C(O)C2O</smiles>

L-Glycero-D-manno heptose<smiles>O=C(O)C1(O)C[C@@H](O)C(O)C(CO)O[C@H]1C(O)CO</smiles>

3-Deoxy-2-keto-octulosonic acid<smiles>OC1OCC2OC(C2O)C(O)C(O)C1O</smiles>

Glucosamine<smiles>O[C@H]1O[C@H](O)[C@H](O)[C@H]1O</smiles>

Apiose<smiles>CC1COC(O)C(O)C(O)C1O</smiles>

L-Fucose<smiles>OC1OC2OC(C2O)C(O)C(O)C1O</smiles>

L-Rhamnose<smiles>O=C1OC(O)C(O)C(O)C(O)C1O</smiles>

D-Glucorunic acid<smiles>OC[C@H]1COC[C@@H](O)[C@@H](O)[C@H]1O</smiles>

D-Fructose<smiles>O[C@H]1C[C@@H](O)CO[C@H]1O</smiles>

2-Deoxyribopyranose

Fig. 1 | Some naturally occurring monosaccharides.

heptose $(n=7)$, etc. and the types of functional groups that are present.

(+)-D-glucose, also known as grape sugar, is the most abundant monosaccharide found in nature followed by (+)-D-mannose and (+)-Dgalactose. ${ }^{3}$ On the other hand, (+)-D-fructose is the sweetest of all naturally occurring carbohydrates and regarded as 1.73 times sweeter than sucrose. It is also the most abundant ketose. ${ }^{4}$

Carbohydrates are the most abundant biomolecule and play an important role in a number of biological reactions. ${ }^{4,5}$ They are the main source of energy in most cells. For example, polysaccharides such as starch and glycogen serve as the storage of energy. Cellulose and chitin are important structural components in plants and arthropods respectively. ${ }^{4,8}$ The 5- carbon monosaccharide ribose is an important component of co-enzymes (e.g. ATP, FAD, and NAD) and the backbone of the genetic molecule known as RNA. Likewise, the related deoxyribose is a component of DNA. ${ }^{8}$ Carbohydrates and their derivatives include many important biomolecules that play key roles in the cell-cell recognition, immune system, embryogenesis, hormonal activities, fertilization, preventing pathogenesis, blood clotting, neuronal development, viral and bacterial infections, proliferation of cells and tumour cell metastasis., 4

In recent years, different types of compounds derived from sugars have emerged as powerful and effective catalysts for asymmetric synthesis. They are readily available at a reasonable price, are highly functionalized, and have several well 
<smiles>CC1(C)OC(C(Oc2ccccc2)(c2ccccc2)c2ccccc2)C(Oc2ccccc2)C1c1ccccc1</smiles>

Pd-allylic alkylation 76\% ee

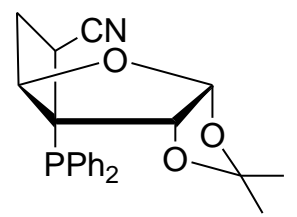

Rh-hydrogenation $92 \%$ ee

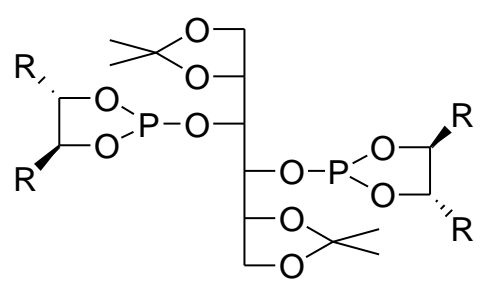

Rh-hydrogenation $<34 \%$ ee<smiles>COC[C@@H]1CN(CCN2[C@H](COC)C(OC)[C@@H](OC)[C@H]2COC)[C@H](COC)C1OC</smiles>

Zn-1,2-addition $82 \%$ ee<smiles>CC1(C)OC2OC3CC(Cc4ccccc4)OC(C3O2)C1(C)C</smiles>

Ni-Cross-coupling 100\% ee<smiles>[R]P(OC([R])([R])C)OC([R])([R])C1COC(C)(C)O1</smiles>

Rh-hydroboration $23 \%$ ee

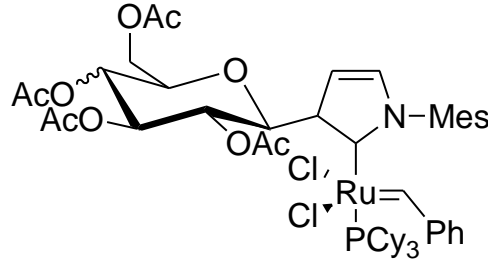

Ru-olefin metathesis $88 \%$ ee

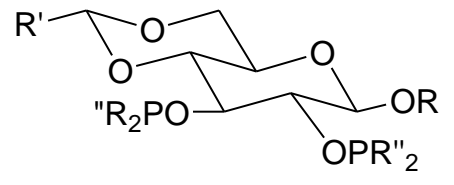

Ni-hydrocyanation $91 \%$ ee

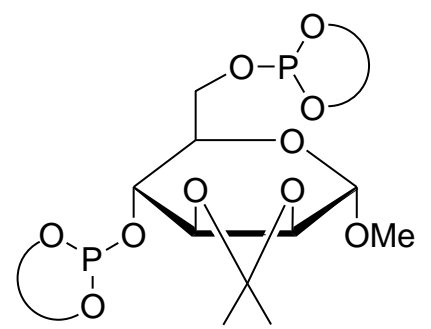

Rh-hydroformylation $64 \%$ ee

Fig. 2 | Some chiral catalysts used for various asymmetric transformation.

defined stereogenic centres. Most of them are employed as chiral ligands (Fig. 2) in metal based asymmetric catalysis and are used for various asymmetric transformations. ${ }^{9-15}$

Recently, different compounds derived from sugars are also used as organocatalyst for asymmetric synthesis. In continuation with our efforts to explored different types of organocatalysts used for asymmetric Michael addition, ${ }^{16}$ here we will highlight a short historical review on the synthesis and applications of sugar derived chiral organocatalysts for the said reaction.

\section{Michael addition using sugar derived or- ganocatalysts}

Though asymmetric Michael addition using organocatalysts has been well documented, there are only few reports of sugar derived organocatalysts used for enantioselective Michael addition. In 2007, Liu et al. ${ }^{17}$ reported a highly enantioselective Michael addition of aromatic ketones to nitro olefins promoted by bifunctional thiourea catalyst (2) readily prepared from commercially available $\beta$-D-glucopyranose (1) via acetylation, bromination, substitution reac- 
tion and subsequent addition of chiral 1, 2cyclohexyldiamines (Scheme 1). The other two thiourea catalyst $2 \mathrm{c}$ and $\mathbf{2 d}$ were synthesised from maltose and lactose, respectively. With catalyst $\mathbf{2 b}$, Michael addition adducts was obtained in good yields (up to 99\%) and high enantioselectivity (up to 98\%) (Scheme 2). The origin of enantioselectivity seems to arise from the attack of the enamine to the si-face of the nitro olefins as the re-face attack was block by cyclohexyl group of the catalyst (Fig. 4).

In 2008, Gao et al ${ }^{18}$ employed bifunctional thiourea organocatalysts $3 a, 3 b$ and $3 c$ (Fig. 5) synthesised from $\alpha$-D-glucopyranose, galactose and lactose, respectively for asymmetric Michael addition of acetyl acetone to nitro olefins. Using $\beta$-nitrostyrene as a test substrate, thiourea 3a gave the best result in terms of enantioselectivity. The reaction was done at $-40{ }^{\circ} \mathrm{C}$ using exactly $10 \mathrm{~mol} \%$ catalyst and $\beta$-nitrostyrene concentration of $0.4 \mathrm{M}$ in toluene to get the best possible result. Under the optimized condition, the versatility of the reaction was investigated using various nitro olefins. The reactions gave up to $>99 \%$ yield and up to $96 \%$ enantioselectivity (Scheme 3).

In the same year Li et al. ${ }^{19}$ also reported enantioselective Michael addition of malonates to nitroolefins catalyzed by chiral bifunctional tertiary amine-thioureas based on saccharides (Fig. 6). Using $\mathbf{4 a}$ and $\mathbf{4 b}$ as catalysts in the presence of toluene as a solvent and at $-20^{\circ} \mathrm{C}$, the reaction gave up to $99 \%$ yield and $99 \%$ ee (Scheme 4).

$\mathrm{Pu}$ et al. ${ }^{20}$ developed a series of new organocatalysts (7) from both $\alpha$-amino acids and carbohydrates (Figure 7) which were consequently used for asymmetric Michael addition of acetylacetone to nitroolefins. The catalysts were readily prepared by coupling amines (5) derived from $\alpha$-amino acids and isothiocyanate (6) derived from D-glucopyranose (Scheme 5). They also described the "matched" and "mismatch" effect of two different chiral units in a chiral organocatalysts, in which both the enantiomers of the product was obtained in almost the same enantioselectivity with "matched" and "mismatched" organocatalysts simply by changing the solvent system from THF to toluene. With 7a (derived from L-valine and D-glucopyranose), addition of acetylacetone to $\beta$-nitrostyrene gave $88 \%$ yield and $85 \%$ enantiomeric excess having (S)configuration when THF was used as a solvent.

On the other hand, the use of 7a' (derived from $\mathrm{D}$-valine and $\mathrm{D}$-glucopyranose) in THF gave the opposite enantiomer with lower enantioselectivity $(76 \%$ ee) which suggest that L- configuration of valine matched the D-glucopyranose, whereas D- configuration of valine mismatched the D-glucopyrano se. But, by changing the solvent from THF to toluene, 7a' gave the product with the opposite absolute configuration in almost the same enantiomeric excess (86\%).

Doubly stereo controlled catalytic conjugate addition of acetylacetone to nitroolefins was also achieved with thiourea catalyst 7e and 7e' in the same solvent (i.e. toluene). Addition of acetylacetone to a variety of nitroolefins in the presence of 7e and 7e' gave the desire products with $(S)$ or (R) configuration (Scheme 6 \& 7) in high yields (up to $90 \%$ ) and good enantioselectivity (up to $91 \%$ ).

Lu et al. ${ }^{21}$ also reported a newly designed pyrrolidine thioureas for asymmetric Michael addition of cyclohexanone to nitro olefins. (S)- or (R)tert-butyl 2-(amino-methyl)pyrrolidine-1carboxylate (8) coupled with glucosyl isothiocyanate (6) to give the catalysts (Scheme 8). With 9a, the reactions gave $\checkmark$-nitroketones with good yields (up to $>99 \%$ ) and excellent diastereo- (up to $>99 / 1 d r$ ) and enantioselectivity (up to $97 \%$ ee) (Scheme 9). They proposed a transition state in which nucleophilic attack of the enamine to the nitroolefin from re-face resulted in the formation of the desired product (Figure 8).

Another new class of carbohydrate-based bifunctional organocatalysts for nucleophilic Michael addition to nitroolefins and imines was reported by Puglisi et al. ${ }^{22}$ They prepared the catalysts from readily available D-glucosamine to prepare 11a-d, which were subsequently converted to the desired thiourea catalysts as shown in the Scheme 9 and 10. With 12b, addition of acetylacetone to nitroolefins gave up to 93\% yield and up to $83 \%$ enantioselectivity (Scheme 12). Asymmetric addition of diethyl malonate to $\mathrm{N}-\mathrm{BOC}$ imine of benzaldehyde was 


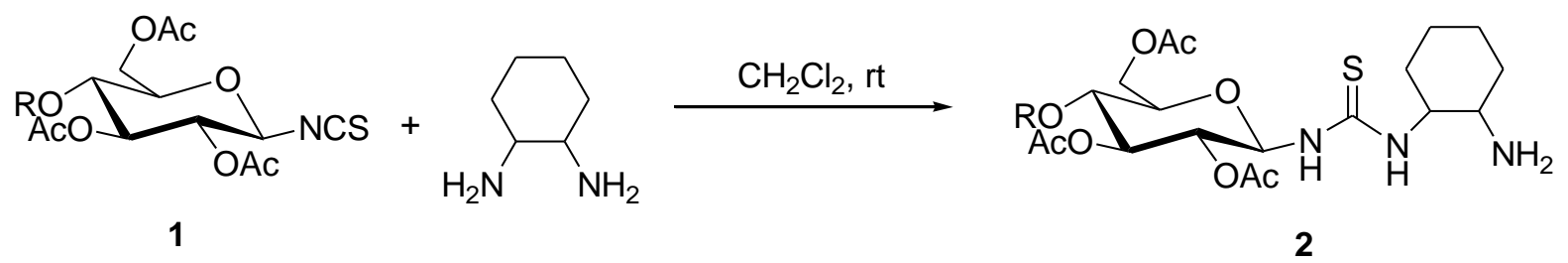

Scheme 1 | Synthesis of primary amine-thiourea catalyst.

$$
\text { 至 }
$$

Scheme 2 | Enantioselective Michael addition using thiourea catalyst 2.

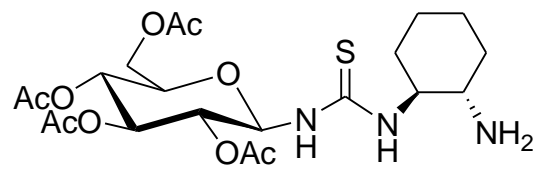

$2 a$

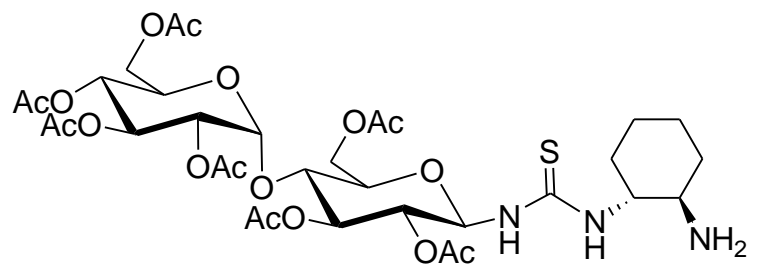

2c

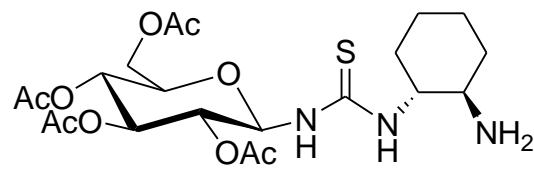

$2 b$

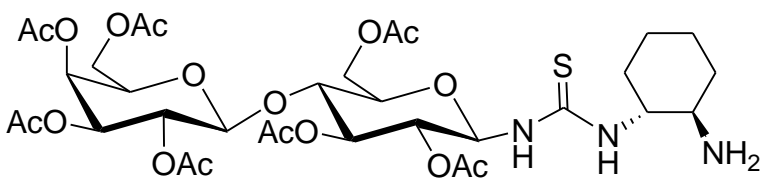

2d

Fig. 3 | Sugar derived organocatalyst used for asymmetric Michael addition.

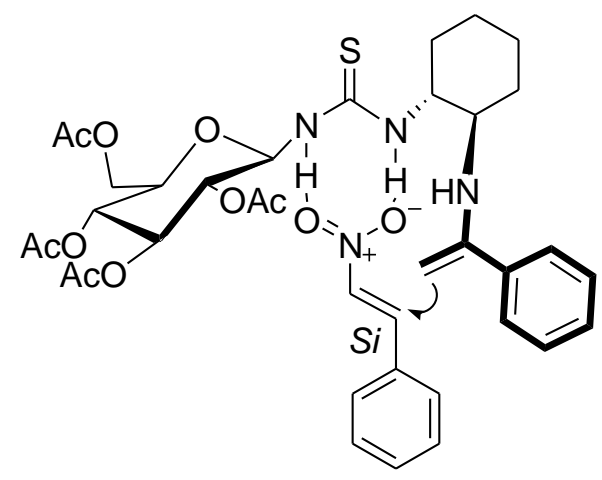

Fig. 4 | Transition sate model. 


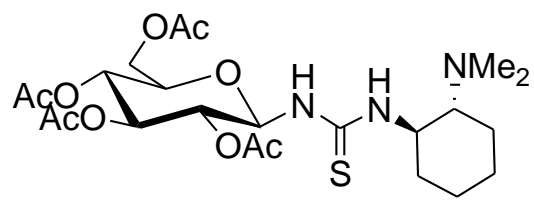

3a

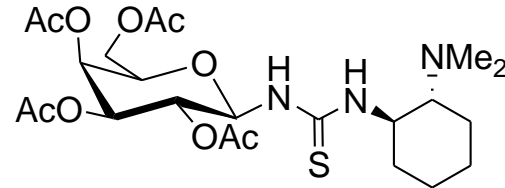

$3 \mathbf{b}$

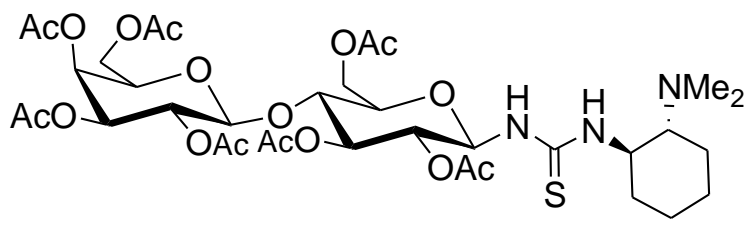

$3 c$

Fig. 5 | Bifunctional thiourea catalysts from sugars.

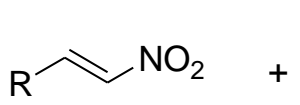<smiles>CC(=O)CC(C)=O</smiles>

$310 \mathrm{~mol} \%$

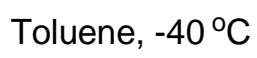<smiles>[R]C(C[N+](=O)[O-])C(C(C)=O)C(C)=O</smiles>

Yield $=$ Upto $99 \%$ ee $=$ Upto $96 \%$

Scheme 3 | Asymmetric Michael addition of acetylacetone to nitroolefins using 3.

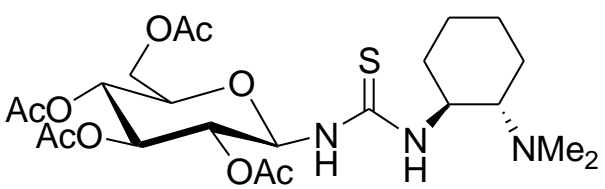

$4 a$

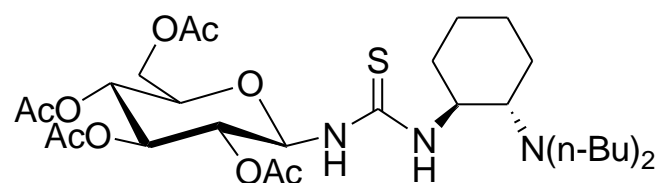

$4 b$

Fig. 6 | Saccharides based bifunctional tertiary amine-thioureas catalysts.

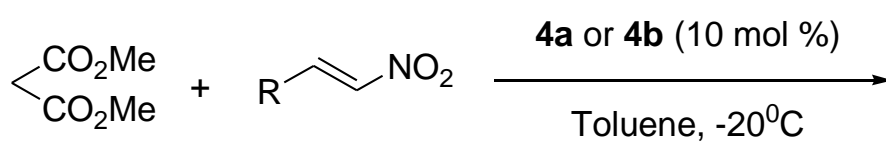<smiles>[R]C(C[N+](=O)[O-])C(C(C)=O)C(=O)OC</smiles>

Yield = Upto 99\% ee $=$ Upto 99\%

Scheme 4 | Enantioselective Michael addition of malonates to nitro olefins. 


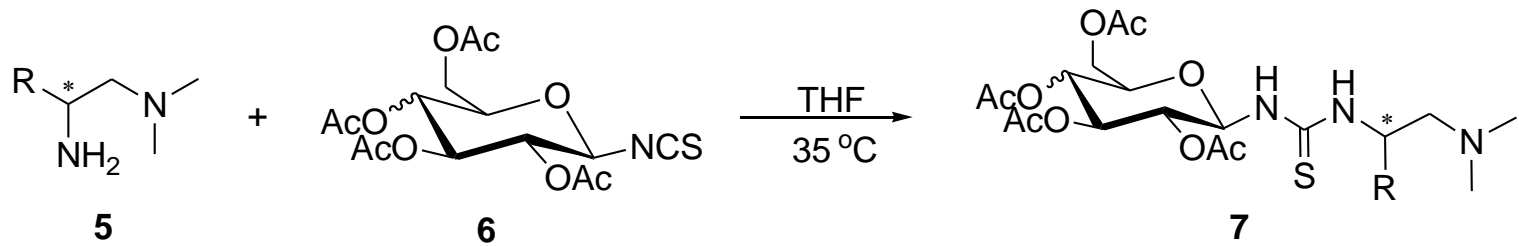

Scheme 5 | Synthesis of thioureacatalyst 7.

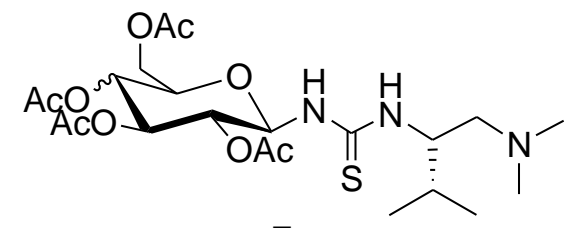

$7 a$

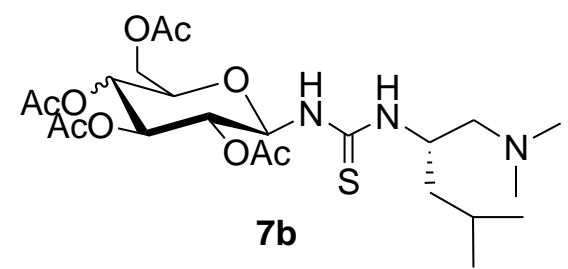

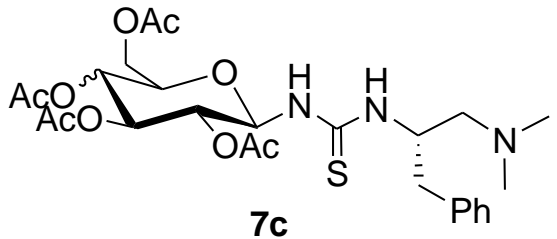

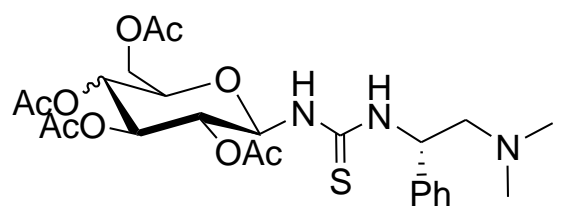

$7 d$

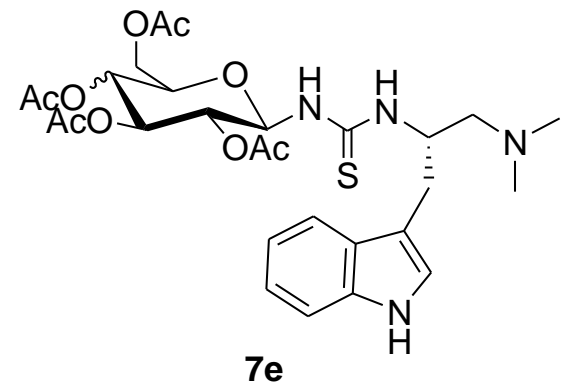

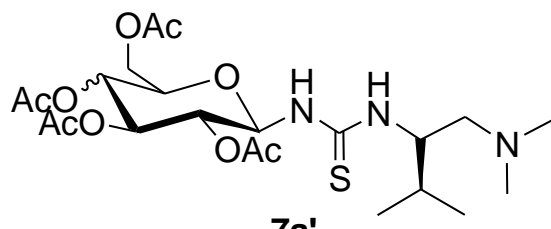

7a'

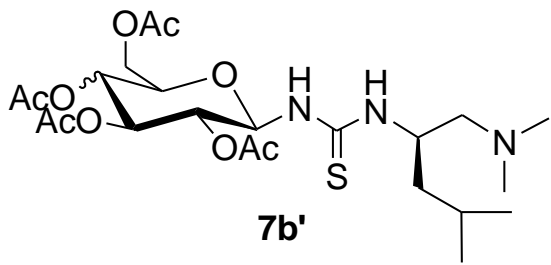

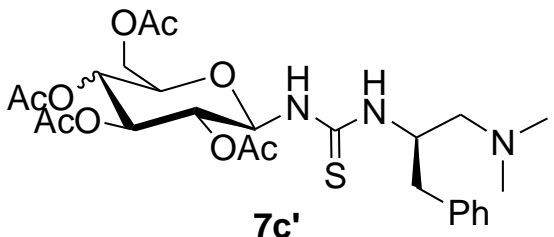

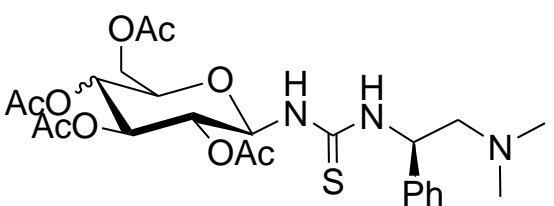
7d'

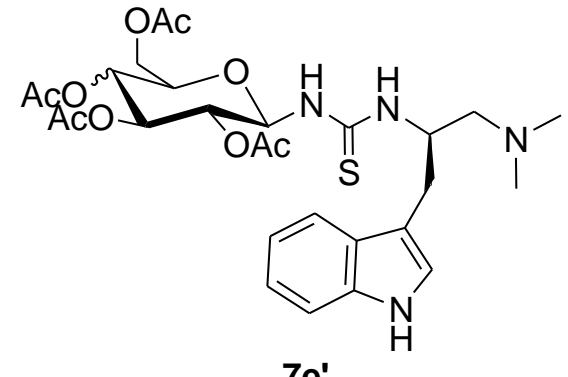

Fig. 7 | Different thiourea catalyst derived from amino acids and carbohydrates. 


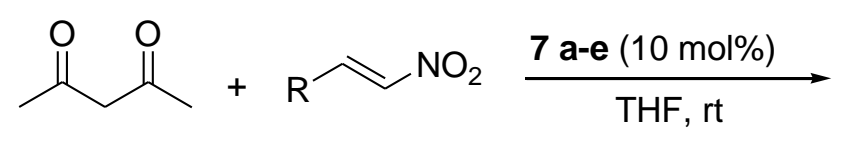<smiles>[R]C(C[N+](=O)[O-])C(C(C)=O)C(C)=O</smiles>

Yield = Upto $88 \%$ ee $=$ Upto $90 \%$

Scheme 6 | Asymmetric addition of acetylacetone to nitroolefins giving (S) configuration.

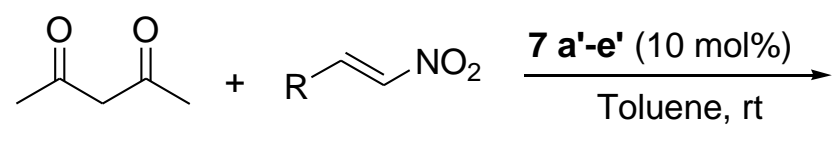<smiles>[R]C(C[N+](=O)[O-])C(C(C)=O)C(C)=O</smiles>

Yield = Upto $88 \%$ ee $=$ Upto $90 \%$

Scheme 7 | Asymmetric addition of acetylacetone to nitroolefins giving (R) configuration.

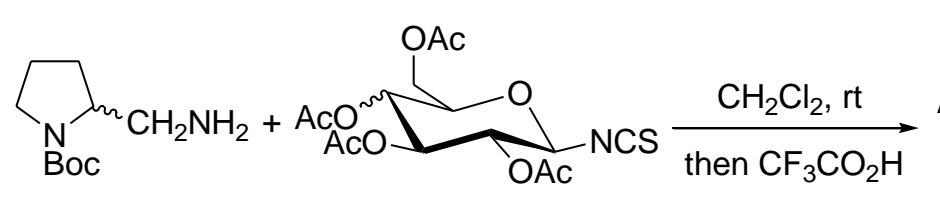

8 6

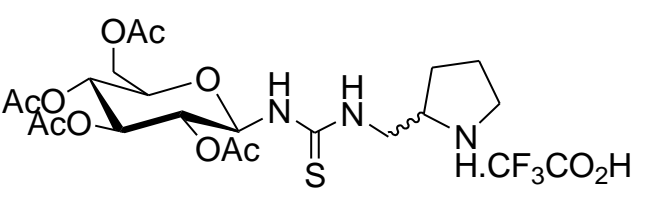

9a : (S)-Pyrrolidine thiourea $9 \mathrm{~b}:(\mathrm{R})$-Pyrrolidine thiourea

Scheme 8 | Synthesis of pyrrolidine thiourea catalyst.<smiles>[R]C=C[N+](=O)[O-]</smiles><smiles>[R5]C(=O)OC(=O)OC(=O)O</smiles>

9a (20 mol\%)

$\operatorname{PrCOOH}(10 \mathrm{~mol} \%),-15^{\circ} \mathrm{C}$<smiles>[R]C(C[N+](=O)[O-])[C@H]1CCCCC1=O</smiles>

Yield = Upto $99 \%$ dr = Upto 99/1 (syn/anti) ee $=$ Upto $97 \%$

Scheme 9 | Asymmetric addition of cyclohexanone to nitro olefins.

Fig. 8 | Proposed transition model.

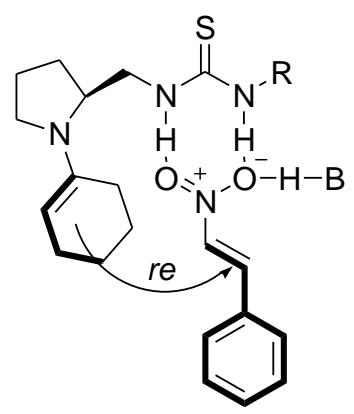

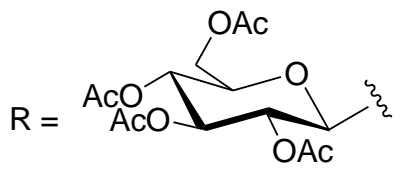




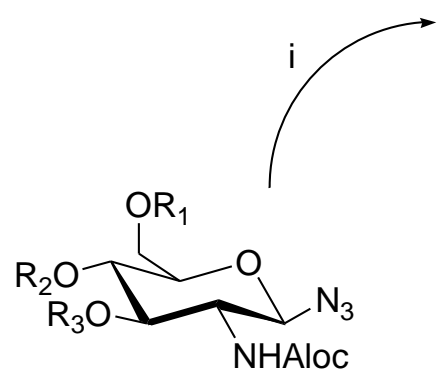

10a: $R_{1}=R_{2}=R_{3}=A c$

10b: $R_{1}=R_{2}=R_{3}=$ TES

10c: $R_{1}, R_{2}=P h C H, R_{3}=$ TES

10d: $R_{1}=R_{2}=R_{3}=M e$

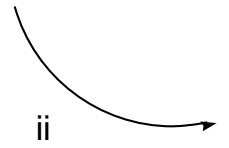

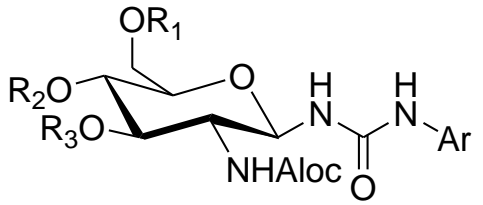

11a: $R_{1}=R_{2}=R_{3}=A c$

11b: $R_{1}=R_{2}=R_{3}=$ TES

11c: $R_{1}, R_{2}=P h C H, R_{3}=$ TES<smiles>FC(F)(F)c1cc(C=[Al])cc(C(F)(F)F)c1</smiles><smiles>CC#CC</smiles>

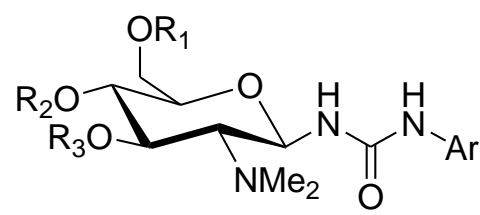

iii

12a: $R_{1}=R_{2}=R_{3}=A c$

12b: $R_{1}=R_{2}=R_{3}=$ TES

12c: $R_{1}, R_{2}=P h C H, R_{3}=$ TES

12d: $R_{1}=R_{2}=R_{3}=M e$

12e: $R_{1}=R_{2}=R_{3}=H$
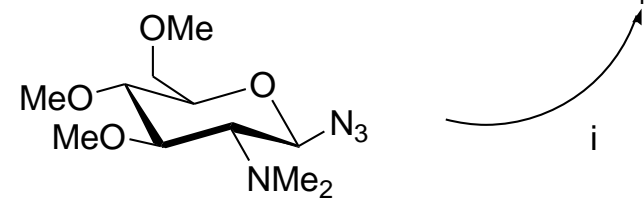

11d

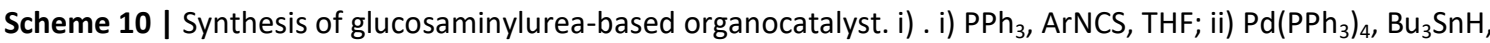
$\mathrm{AcOH}, \mathrm{CH}_{2} \mathrm{Cl}_{2}$, then $\mathrm{HCHO}, \mathrm{NaCNBH}_{3}$, THF; iii) $\mathrm{NaOMe}, \mathrm{MeOH}$, (qu).

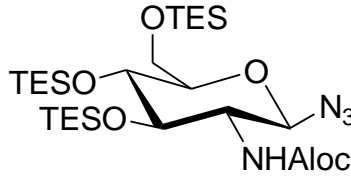

$10 b$

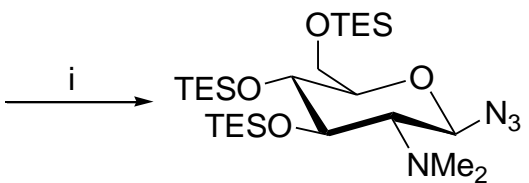

$11 f$

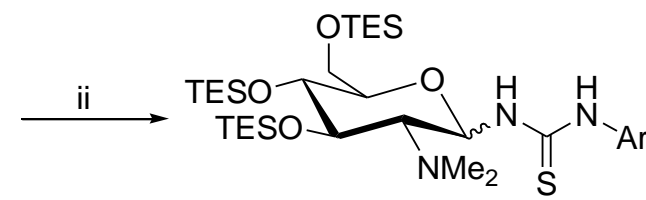

$12 f$

Scheme 11 | Synthesis of glucosaminylurea-based organocatalyst 12f. i) $\mathrm{Pd}\left(\mathrm{PPh}_{3}\right)_{4}, \mathrm{Bu}_{3} \mathrm{SnH}, \mathrm{AcOH}, \mathrm{CH}_{2} \mathrm{Cl}_{2}$, then $\mathrm{HCHO}, \mathrm{NaCNBH}_{3}$, THF (57\%); ii) $\mathrm{H}_{2}, \mathrm{Pd} / \mathrm{C}, \operatorname{ArNCS}, \mathrm{THF}(46 \%)$.<smiles>[R]C=C[N+](=O)[O-]</smiles><smiles>CC(=O)CC(C)=O</smiles>

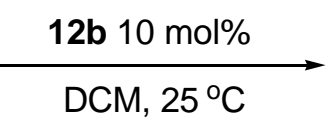

Yield = Upto 93\% ee $=$ Upto $83 \%$

Scheme 12 | Asymmetric Michael addition of acetylacetone to nitroolefins with $\mathbf{1 2 b}$. 


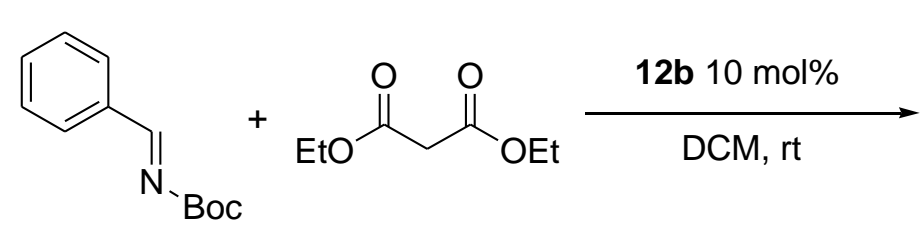<smiles>CCOC(=O)C(C(=O)OCC)C(NC(=O)OCc1ccccc1)c1ccccc1</smiles>

Yield $=25 \%$ ee $=81 \%$

Scheme 13 | Asymmteric Michael addition of diethyl malonate to $N$-Boc imine.

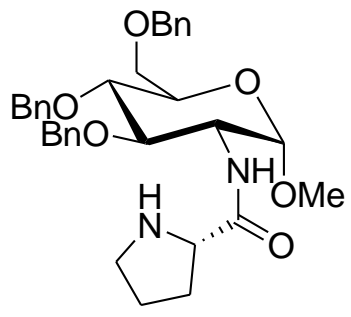

$13 a$

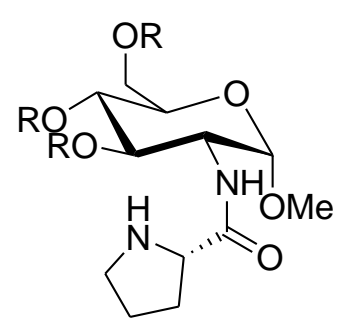

$13 b$

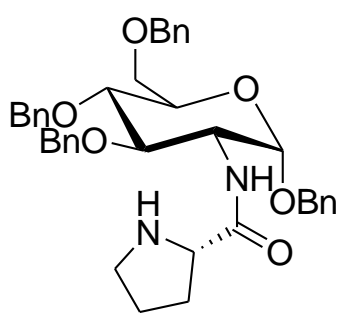

$13 c$

Fig. 9 | Sugar based prolinamides from L-proline and D-glucosamine.<smiles>[R]C1CCC(=O)CC1</smiles>

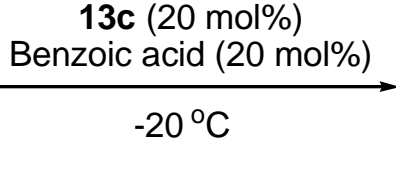<smiles>[R7]C1C=C([C@H](C[N+](=O)[O-])c2[R]cccc2)C(=O)CC1</smiles>

Yield = upto $98 \%$ $\mathrm{dr}=$ upto $99: 1$ (anti/syn) er $=$ upto $84: 16$ (syn)

Scheme 14 | Asymmetric addition of cyclohexanone to nitroolefins with 13c. 
<smiles>COC1OC(CBr)C(OC)C(OC)C1OC</smiles>

14<smiles>COC1[C@H](OC)[C@@H](OC)O[C@@H](CN)[C@H]1OC</smiles>

15<smiles>COC1[C@H](OC)[C@@H](OC)OC(CN)[C@H]1N[PH]</smiles><smiles>[R]NC1C(CNC(=S)NP)OC(OC)C(OC)C1OC</smiles>

17a $\mathrm{R}=\mathrm{cHexyl}$ 17b R = Benzyl

18a $R=$ cHexyl, $R^{\prime}=P h$

18b $\mathrm{R}=\mathrm{cHexyl}, \mathrm{R}^{\prime}=3,5-\mathrm{CF}_{3} \mathrm{Ph}$

18c $R=$ Benzyl, $R^{\prime}=\mathrm{Ph}$

18d $R=$ Benzyl, $R^{\prime}=3,5-C_{3} P h$

Scheme 15 | Synthesis of the catalysts; (a) $\mathrm{NaN}_{3}, \mathrm{DMF}, 70^{\circ} \mathrm{C}, 6 \mathrm{~h}, 94 \%$; (b) $\mathrm{NaOMe}, \mathrm{MeOH}, \mathrm{rt}, 1 \mathrm{~h}, 80 \%$; (c) (i) $\mathrm{Tf}_{2} \mathrm{O}$, pyridine, $\mathrm{CH}_{2} \mathrm{Cl}_{2}, 0 \mathrm{oC}, 2 \mathrm{~h}$, (ii) amine, DMF, $45^{\circ} \mathrm{C}, 10 \mathrm{~h}, 50-70 \%$; (d) (i) propanedithiol, $\mathrm{MeOH}, \mathrm{rt}, 48 \mathrm{~h}$ (18a and 18b), or $\mathrm{PPh}_{3}, \mathrm{H}_{2} \mathrm{O}, \mathrm{THF}, 80^{\circ} \mathrm{C}$, (18c and 18d), (ii) isothiocyanate, $\mathrm{MeOH}, \mathrm{rt}, 4 \mathrm{~h}, 30-50 \%$.<smiles>CO[C@H]1OC(CBr)[C@H](OC)[C@H](OC)[C@H]1OC</smiles>

14<smiles>COC1C(OC)[C@H](OC)C(CN2CCCCC2)O[C@H]1C</smiles>

19<smiles>CO[C@H]1O[C@H](CN2CCCCC2)[C@@H](O)[C@H](OC)[C@H]1O</smiles>

20<smiles>CO[C@@H]1[C@H](C)O[C@H](CN2CCCCC2)[C@@H](OC)[C@@H]1OC</smiles>

21<smiles>COC1OC(CN2CCCCC2)[C@H](NC(=S)Nc2ccccc2)C(OC)C1OC</smiles>

22

Scheme 16 | Synthesis of organocatalysts; (a) piperidine, DMF, $70^{\circ} \mathrm{C}, 50 \mathrm{~h}, 90 \%$; (b) $\mathrm{NaOMe}, \mathrm{MeOH}$, reflux, $2 \mathrm{~h}, 85 \%$; (c) $\mathrm{Tf}_{2} \mathrm{O}$, pyridine, $\mathrm{DCM}, 0^{\circ} \mathrm{C}, 2 \mathrm{~h}$, (ii) $\mathrm{NaN}_{3}, \mathrm{DMF}, 45^{\circ} \mathrm{C}, 72 \mathrm{~h}, 40 \%$; (d) (i) propanedithiol, $\mathrm{MeOH}, \mathrm{rt}, 48 \mathrm{~h}$, (ii) phenyl isothiocyanate, $\mathrm{MeOH}, \mathrm{rt}, 8 \mathrm{~h}, 69 \%$. 
<smiles>CO[C@H]1O[C@@H]2COC(c3ccccc3)O[C@H]2[C@H]2O[C@H]12</smiles>

23<smiles>COC1O[C@@H]2COC(c3ccccc3)O[C@H]2[C@H]1O</smiles>

24a $\mathrm{R}=\mathrm{CH}_{2}$ 24b $\mathrm{R}=\mathrm{O}$<smiles>CO[C@H]1O[C@@H]2COC(c3ccccc3)O[C@H]2[C@H](N)[C@H]1N1CCPCC1</smiles>

25a $\mathrm{R}=\mathrm{CH}_{2}$ 25b $R=O$

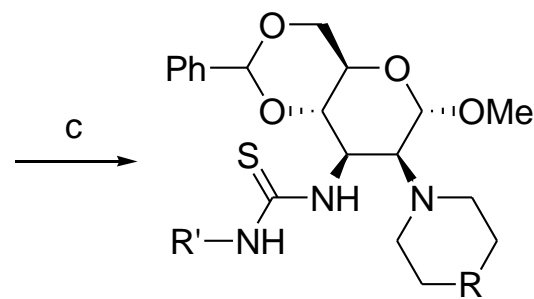

26a $\mathrm{R}=\mathrm{CH}_{2}, \mathrm{R}^{\prime}=\mathrm{Ph}$

26b $\mathrm{R}=\mathrm{CH}_{2}, \mathrm{R}^{\prime}=3,5-\mathrm{CF}_{3} \mathrm{Ph}$

26c $R=O, R^{\prime}=P h$

26d $R=O, R^{\prime}=3,5-C_{3} P h$

Scheme 17 | Synthesis of catalysts 26; (a) piperidine or morpholine, $\mathrm{LiClO}_{4}, \mathrm{MeCN}, 90^{\circ} \mathrm{C}, 24 \mathrm{~h}, 80-90 \%$; (b) (i) $\mathrm{PPh}_{3}$, DIAD, THF, $0^{\circ} \mathrm{C}$, (ii) DPPA, THF, rt, $24 \mathrm{~h}, 60-80 \%$; (c) (i) $\mathrm{PPh}_{3}, \mathrm{THF}, \mathrm{H}_{2} \mathrm{O}, 80^{\circ} \mathrm{C}$, (ii) isothiocyanate, $\mathrm{MeOH}, \mathrm{rt}, 8 \mathrm{~h}, 60$ $80 \%$.<smiles>O=[N+]([O-])C=Cc1ccccc1</smiles><smiles>CC(=O)CC(C)=O</smiles><smiles>CC(=O)C(C(C)=O)C(C[N+](=O)[O-])c1ccccc1</smiles>

Scheme 18 | Michael addition of acetylacetone to $\beta$-nitrostyrene using 18, 22 and 26.

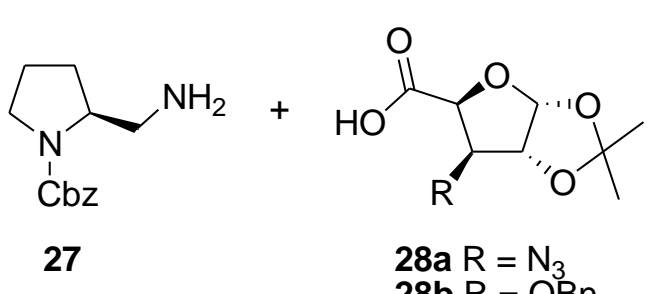

$$
\text { 28b } R=O B n
$$<smiles>CCCCCC(=O)OCc1ccccc1</smiles>

$\mathrm{CH}_{2} \mathrm{Cl}_{2}$, rt, 8 h, $81 \%$<smiles>CC1(C)O[C@H]2OC(C(=O)NCC3CCCN3)[C@H](N)[C@H]2O1</smiles>

30 $\underset{\mathrm{rt}, 12 \mathrm{~h}}{\stackrel{\mathrm{Pd} / \mathrm{C}, \mathrm{H}_{2}, \mathrm{CH}_{3} \mathrm{OH}}{\longrightarrow}}$<smiles>[R]C1C(C(=O)NCC2CCCN2C(=O)O)OC2OC(C)(C)OC21</smiles>

29a $\mathrm{R}=\mathrm{N}_{3}$

29b $R=O B n$ or<smiles>CC1(C)O[C@H]2OC(C(=O)NCC3CCCN3)C(O)[C@H]2O1</smiles>

31

Scheme 19 | Sugar amide-pyrrolidine catalyst for the asymmetric Michael addition. 


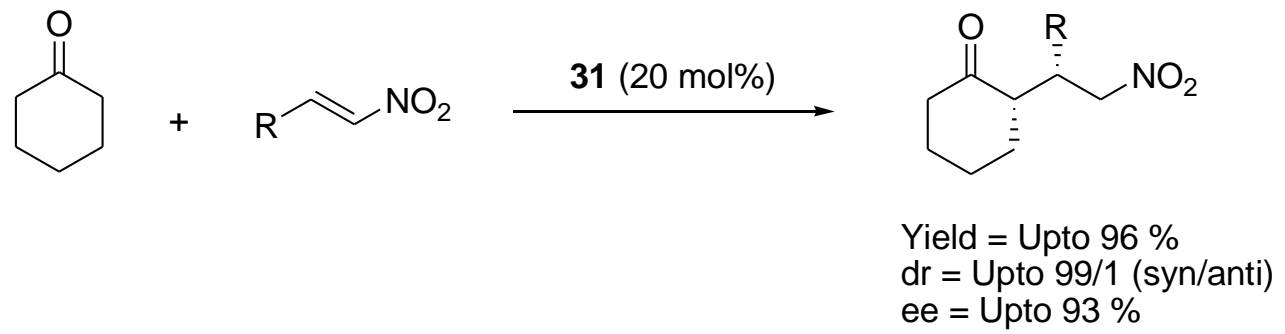

Scheme 20 | Asymmetric Michael addition of ketones to nitroolefins using catalyst 31.<smiles>CC1(C)OCC(C2[C@@H]([C@H]3O[C@@H]4OC(C)(C)O[C@H]4C3=O)COC2(C)C)O1</smiles>

32<smiles>CC1(C)OC[C@H]([C@H]2O[C@@H]3OC(C)(C)O[C@@H]3[C@]2(O)CNC(=S)Nc2cc(C(F)(F)F)cc(C(F)(F)F)c2)O1</smiles>

33<smiles>CC1(C)O[C@H]2O[C@H]([C@H](O)CO)[C@](O)(CNC(=S)Nc3cc(C(F)(F)F)cc(C(F)(F)F)c3)[C@H]2O1</smiles>

Scheme 21 | Synthesis of thiourea derived 3-C-aminomethyl-hexafuranose (35).<smiles>O=C(/C=C/c1ccccc1)c1ccccc1</smiles><smiles>O=C(CC(C[N+](=O)[O-])c1ccccc1)c1ccccc1</smiles>

Configuration $=S$

Yield $=30 \%$ $e e=48 \%$

Scheme 22 | Organocatalyst $\mathbf{3 5}$ catalyzed Michael addition of nitromethane to trans-chalcone.

also investigated using $\mathbf{1 2 b}, \mathbf{1 2 c}, \mathbf{1 2 d}$ and $\mathbf{1 2 f}$. In terms of enantioselectivity, $\mathbf{1 2 b}$ gave the best result ( $81 \%$ ee) but the yield was low (25\% only) (Scheme 14).

Agarwal and Peddinti ${ }^{23}$ also describe a sugarbased prolinamides organocatalysts for asymmetric Michael addition in solvent-free condition. The catalysts (13a-13c, Fig. 9) were prepared from commercially available L-proline and $\mathrm{D}$-glucosamine. The reaction condition was found to be optimum at $-20^{\circ} \mathrm{C}$ in the absence of solvent with $20 \mathrm{~mol} \%$ catalysts and another 20 mol\% organic acid additive (benzoic acid). The Michael adducts were obtained in excellent yields (up to 98\%), high diastereoselectivity (up to $99 / 1$ ) and moderate enantioselectivity (er up to $84 / 16$ for syn) (Scheme 14). The catalytic system was found to provide $(1 \mathrm{R}, 2 \mathrm{~S})$-syn adducts as a major antipodes.

In 2014, Agoston and Fugedi ${ }^{24}$ designed and prepared a group of new-bifunctional-thioureaamine catalysts starting from D-glucose. The 
two catalytic centres in those molecules synthesised were connected by a carbohydrate residue. The catalysts were designed in such a way that the catalytic centers were placed at various positions of the carbohydrate scaffold to see the possible effect arising from carbohydrate chirality. So, they synthesized molecules having the amino and thioureido groups in positions 4 and 6 , or in positions 2 and 3 of the carbohydrate scaffold. Methyl 4-O-benzoyl-6-bromo-6-deoxy2,3-di-O-methyl- $\alpha$-D-glucopyranoside (14) which was prepared from methyl $\alpha$-D-glucopyranoside was used as a starting material for the preparation of catalysts having the catalytic groups in the 4 and 6 position (Scheme 15 \& 16).

The synthesis of 2-amino-3-thioureido derivatives (26a-d) started from allo-epoxide (23) as starting material which was further prepared from commercially available methyl $\alpha-\mathrm{D}$ glucopyranoside (Scheme 17).

The catalysts synthesised were used for Michael addition of acetylacetone to $\beta-$ nitrostyrene (Scheme 18). It was found that only those compounds having secondary amine groups were able to promote the reaction (up to $78 \%$ yield). The active catalysts favoured the formation of Michael adduct having $S$ configuration, but enantioselectivity is very low (up to $18.7 \%$ only).

Recently, Kumar and Balaji25 developed new sugar based pyrrolidine-amide catalysts (30 and 31) derived from L-proline and the furanose form of D-glucose and used it for asymmetric Michael addition of ketones to nitroolefins (Scheme 19).

Catalyst 30 gave good yields and diasterioselectivities but low enantioselectivities (up to $21 \%$ only). The best results were observed with catalyst 31 in which 20 mol\% of the catalyst was used under solvent free condition. Up to $96 \%$ yield, 99:1 (syn/anti) diastereoselectivity and up to $93 \%$ ee were obtained (Scheme 20).

More recently, Turks et al. ${ }^{26}$ also reported the synthesis of thiourea derived 3-C-aminomethylhexafuranose (35) which was employed for the asymmetric addition of nitromethane to transchalcone (Scheme 21). The reaction took place over 14 days and gave the product in 30\% yield and $48 \%$ ee.

\section{Conclusion}

Different types of compounds derived from sugars are used recently as organocatalyst for asymmetric synthesis. These are due to their commercial availability, low cost and inertness towards moisture and air. The catalysts described in this paper mainly showed high yield and enantioselectivity leading to huge demand and widespread utility. The highest yield and enantioselectivity (both 99\%) were seen in Michael addition of malonates to nitroolefins catalyzed by chiral bifunctional tertiary aminethioureas based on saccharides in the presence of toluene as a solvent and at $-20^{\circ} \mathrm{C}$. However, the lowest yield and enantioselectivity, 30\% and $48 \%$ respectively were seen in the synthesis of thiourea derived 3-C-aminomethylhexafuranose which was employed for the asymmetric addition of nitromethane to transchalcone. As organic catalysts are easily available, cheap, easily prepared and are useful in complex steric reactions, they may be used as an alternative to the present transition metals catalysis.

\section{Acknowledgement}

The author KVL gratefully acknowledges UGC, Government of India, for Major Research Project, Grant No: UGC F.No.- 43-210/2014(SR), for financial support.

\section{References}

I. Lindhorst, T.K. (2007). Essential of Carbobydrates Chemistry and Biochemistry. Wiley-VCH Verlag GmdH \& Co., Wienheim, Germany.

2. Bochkov, A.F. \& Zaikov, G.E. (199I). Carbohydrates. VSP BV, Zeist, Netherland, p. I-2.

3. Collins, P. \& Ferrier, R. (1995). Monosaccharides. John Wiley \& Sons, Ltd., Chichester, UK.

4. Boons, G.J. \& Hale, K. (200o). Organic Synthesis with Carbobydrates. Sheffield Academic Press Ltd., Sheffield, England. 
5. Miljković, M. (2010). Carbohydrates: Synthesis, Mechanisms and Stereoelectronic Effects. Springer Science + Business Media, LLC, NY, USA, p. I.

6. Stick, R.V. \& Williams, S.J. (2009). Carbohydrates: the essential molecules of life. Elsevier, Oxford, UK, $2^{\text {nd }}$ Edition, p. I.

7. Hanover, L.M. \& White, J.S. (1993). Manufacturing, composition, and application of fructose. Journal of Clinical Nutrition. 58, 724.

8. Maton, A., Hopkins, J., McLaughlin, C.W., Johnson, S., Warner, M.Q., LaHart, D. \& Wright, J.D. (1993). Human Biology and Health. Englewood Cliffs, New Jersey, USA, Prentice Hall, pp. 52.

9. Diéguez, M., Pàmies, O., \& Claver, C. (2004). Ligands derived from carbohydrates for asymmetric catalysis. Chemical Reviews, 104(6), 3189-3216.

Io. Steinborn, D., \& Junicke, H. (2000). Carbohydrate complexes of platinum-group metals. Chemical Reviews, IOO, 4283-4318.

II. Mata, Y., Diéguez, M., Pamies, O., \& Woodward, S. (2006). Screening of a modular sugar-based phosphite ligand library in the asymmetric nickel-catalyzed trialkylaluminum addition to aldehydes. The Journal of Organic Chemistry, 71, 8159-8165.

I2. Raluy, E., Claver, C., Pàmies, O., \& Diéguez, M. (2007). First chiral phosphoroamidite-phosphite ligands for highly enantioselective and versatile Pd-catalyzed asymmetric allylic substitution reactions. Organic Letters, 9, 49-52.

13. Khiar, N., Navas, R., Álvarez, E., \& Fernández Fernández, I. (2008). New sulfur-phosphine ligands derived from sugars: synthesis and application in palladium-catalyzed allylic alkylation and in rhodium asymmetric hydrogenation. Arkivoc, 2008, 2II-224.

I4. Khiar, N., Navas, R., Suarez, B., Alvarez, E., \& Fernandez, I. (2008). Asymmetric enamide hydrogenation using phosphinite thioglycosides: Synthesis of D-and Laminoesters using D-sugars as catalyst precursors. Organic Letters, Io, 3697-3700.

I5. Samec, J. S., Keitz, B. K., \& Grubbs, R. H. (2010). Latent ruthenium olefin metathesis catalysts featuring a phosphine or an N-heterocyclic carbene ligand. Journal of Organometallic Chemistry, 695, 183I-I837.

16. Vanlaldinpuia, K. \& Lalthanpuii, P.B. (2016). Organocatalysts: A powerful tool for asymmetric Michael addition. Science Vision, 16, 124-134.

I7. Liu, K., Cui, H. F., Nie, J., Dong, K. Y., Li, X. J., \& Ma, J. A. (2007). Highly enantioselective Michael addition of aromatic ketones to nitroolefins promoted by chiral bifunctional primary amine-thiourea catalysts based on saccharides. Organic Letters, 9, 923-925.

I8. Gao, P., Wang, C., Wu, Y., Zhou, Z., \& Tang, C. (2008). Sugar-Derived Bifunctional Thiourea Organocatalyzed Asymmetric Michael Addition of Acetylacetone to Nitroolefins. European Journal of Organic Chemistry, 2008, 4563-4566.

19. Li, X. J., Liu, K., Ma, H., Nie, J., \& Ma, J. A. (2008). Highly enantioselective michael addition of malonates to nitroolefins catalyzed by chiral bifunctional tertiary amine-thioureas based on saccharides. Synlett, 2008, 3242-3246.

2o. (a) Pu, X., Li, P., Peng, F., Li, X., Zhang, H., \& Shao, Z. (2009). Asymmetric Conjugate Addition of Acetylacetone to Nitroolefins with Chiral Organocatalysts Derived from Both $\alpha$-Amino Acids and Carbohydrates. European Journal of Organic Chemistry, 2009, 46224626. (b) Pu, X.W., Peng, F.Z., Zhang, H.B. \& Shao, Z.H. (2010). Tetrabedron. 66, 3655-366I.

2I. Lu, A., Gao, P., Wu, Y., Wang, Y., Zhou, Z., \& Tang, C. (2009). Highly enantio-and diastereoselective Michael addition of cyclohexanone to nitroolefins catalyzed by a chiral glucose-based bifunctional secondary aminethiourea catalyst. Organic E\& Biomolecular Chemistry, 7, 3I4I-3I47.

22. Puglisi, A., Benaglia, M., Raimondi, L., Lay, L., \& Poletti, L. (20II). Novel carbohydrate-based bifunctional organocatalysts for nucleophilic addition to nitroolefins and imines. Organic \&ु Biomolecular Chemistry, 9, 3295-3302.

23. Agarwal, J., \& Peddinti, R. K. (20II). Asymmetric Michael addition catalysed by sugar-based prolinamides in solvent-free conditions. Tetrahedron Letters, 52, II7-I2I.

24. Ágoston, K., \& Fügedi, P. (2014). Preparation of new type of organocatalysts having a carbohydrate scaffold. Carbohydrate Research, 389, 50-56.

25. Kumar, T. P., \& Balaji, S. V. (2014). Sugar amidepyrrolidine catalyst for the asymmetric Michael addition of ketones to nitroolefins. Tetrabedron: Asymmetry, 25, 473-477.

26. Turks, M., Rolava, E., Stepanovs, D., Mishnev, A., \& Marković, D. (2015). Novel 3-C-aminomethylhexofuranose-derived thioureas and their testing in asymmetric catalysis. Tetrabedron: Asymmetry, 26, 952960. 